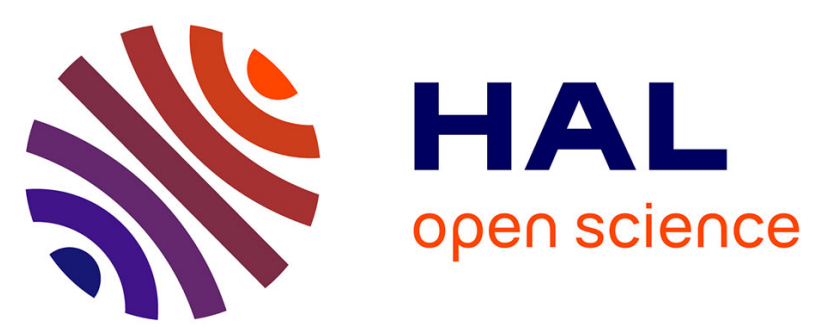

\title{
A general kinetic law for heavy metal vaporization during municipal solid waste incineration
}

Quentin Falcoz, Daniel Gauthier, Stéphane Abanades, Fabrice Patisson, Gilles Flamant

\section{- To cite this version:}

Quentin Falcoz, Daniel Gauthier, Stéphane Abanades, Fabrice Patisson, Gilles Flamant. A general kinetic law for heavy metal vaporization during municipal solid waste incineration. Process Safety and Environmental Protection, 2010, 88, pp.125-130. 10.1016/j.psep.2009.11.009 . hal-01025581

\section{HAL Id: hal-01025581 \\ https://hal.science/hal-01025581}

Submitted on 18 Jul 2014

HAL is a multi-disciplinary open access archive for the deposit and dissemination of scientific research documents, whether they are published or not. The documents may come from teaching and research institutions in France or abroad, or from public or private research centers.
L'archive ouverte pluridisciplinaire HAL, est destinée au dépôt et à la diffusion de documents scientifiques de niveau recherche, publiés ou non, émanant des établissements d'enseignement et de recherche français ou étrangers, des laboratoires publics ou privés. 


\title{
A GENERAL KINETIC LAW FOR HEAVY METAL VAPORIZATION DURING MUNICIPAL SOLID WASTE INCINERATION
}

\author{
Quentin FALCOZ ${ }^{1}$, Daniel GAUTHIER ${ }^{1 *}$, Stéphane ABANADES ${ }^{1}$, Fabrice PATISSON ${ }^{2}$, \\ Gilles FLAMANT ${ }^{1}$ \\ ${ }^{1}$ Laboratoire Procédés Matériaux et Energie Solaire (CNRS-PROMES), 7 Rue du Four Solaire, \\ Odeillo, 66120 Font-Romeu - France \\ ${ }^{2}$ Laboratoire de Sciences et Génie des Matériaux et de Métallurgie (LSG2M), Ecole des Mines de \\ Nancy, Parc de Saurupt, 54000 Nancy
}

\begin{abstract}
:
Metal emissions from waste incineration plants become a great environmental concern because of their toxicity for both human health and environment. Metals are not destroyed by hightemperature thermal treatment and some vaporized metals may be emitted. It is thus essential to understand the release mechanism of metals during high-temperature waste treatment, in order to improve the understanding of their behavior and the control of their emission. The objective of this study is to identify the kinetic law for metal release from realistic artificial waste. The vaporization of three metals of most concern $(\mathrm{Cd}, \mathrm{Pb}$ and $\mathrm{Zn})$ during municipal waste incineration was studied. The vaporization rate at the particle level was determined from the experimental concentration profile in the outlet gas of a fluidized bed reactor, by using the inverse method that was previously developed and validated by our team. As a first step, the kinetic parameters were determined thanks to experiments carried out at several temperatures. Specific laws, for each studied metal, were thus obtained as a function of temperature. Nevertheless, it is very useful to identify all the experimental kinetic curves (all studied metals at all temperatures) to one single mathematical law. Therefore, a general kinetic law, expressing the solid matrix influence on the metal vaporization dynamic, was determined as a second step. It permits to predict the vaporization characteristic time and the time course of the metal concentration in the waste.
\end{abstract}

Keywords: vaporization kinetic, heavy metal, incineration, fluidized bed, model waste * Corresponding author:

Tel: +33468307 757

Fax: +33468302940

e-mail: Daniel.Gauthier@promes.cnrs.fr 


\section{Introduction}

Metal emissions from waste incineration plants become a great environmental concern because of their toxicity for both human health and environment. Metals are not destroyed by hightemperature thermal treatment and the air pollution control devices may not always trap the submicrometer metal particulate and gaseous compounds. Chandler et al. (1997) and Zhang et al. (2008) have shown that vaporized metals can form condensable particulates. Those particulates can then deposit on cool surfaces or be emitted in the atmosphere. The understanding of the different mechanism involved in the heavy metal (HM) vaporization during waste incineration is thus very important ton control and prevent their emissions.

The heavy metal partitioning during incineration is influenced by many factors (Toledo et al. 2005, Corella and Toledo 2000, Belevi and Langmeier 2000, Wey et al. 1996, Barton et al. 1990). Their reaction kinetics, as well as their evaporation, are related to their physico-chemical properties. Some incineration conditions have been identified as important parameters strongly affecting the HM behavior (for instance: furnace temperature, chlorine content, moisture content, retention time or mixing conditions, etc.).

Previous researches dealt mostly with model wastes, investigating the different factors influencing the HM transfer and partitioning during incineration (Abanades et al. 2005, Scharnhorst et al. 2007, Youcai et al. 2004, Marias et al. 2001). Among those factors, oxygen and chlorine contents are key-parameters that influence the final HM distribution between solid and gaseous phases. Besides, many thermodynamic calculations (Frandsen et al. 1994, Abanades et al. 2001, Ménard et al. 2006, Poole et al. 2008) have been realized in order to discuss and predict the HM chemical speciation and fate. 
But the system evolution with time cannot be predicted by thermodynamics calculations only. Thus, the HM evolution must be investigated by kinetic studies. Ho et al. (1993) carried out experiments to study the metal behavior during the thermal treatment of contaminated soil. Kinetics parameters were identified with respect to experimental results in their model.

Previous work in our team concerned the HM vaporization from model wastes in a fluidized bed reactor. Abanades et al. (2005) studied the influence of operating parameters on the HM release in exhaust fumes for both organic and mineral model wastes. Kinetic rate laws of toxic metal release during model incineration in a fluid bed were determined by Liu et al. (2005). A firstorder rate was identified in the case of a mineral matrix, and a second-order rate in the case of a realistic model waste.

Falcoz et al. (2009) studied and identified the kinetic law for metal vaporization from realistic artificial waste $(\mathrm{RAW})$. The behavior of three metals of most concern $(\mathrm{Cd}, \mathrm{Pb}$, and $\mathrm{Zn})$ during municipal solid waste incineration was studied in a high temperature fluidized bed (such a reactor allows a very good control of both temperature and mass transfer). A measurement method involving a customized ICP-OES spectrometer (described before, Falcoz et al. 2007) permitted to obtain concentration profiles by on-line analysis. The vaporization rate at the particle level was determined from the experimental concentration profile in the outlet gas of the fluidized bed reactor, by using the inverse method that was previously developed and validated by our team (Abanades et al.2003).

The kinetic parameters were determined thanks to experiments carried out at several temperatures. Specific laws, for each studied metal, were thus obtained as a function of temperature. Temperature has a strong influence on the HM vaporization dynamics, especially on the vaporization kinetics profile. This phenomenon was attributed to internal diffusion control of the HM release. Two types of kinetics were identified according to temperature: a fourth- or fifth- 
order polynomial rate law $\left(r(x)=k_{0} e^{-E_{A} / R T} p(x)\right)$ for temperatures lower than $740{ }^{\circ} \mathrm{C}$, and a firstorder polynomial $\left(r(x)=k_{0} e^{E_{A} / k r}\left(q-q_{f}\right)\right)$ for temperatures higher than $740{ }^{\circ} \mathrm{C}$.

Nevertheless, it is very interesting to identify all the experimental curves (i.e. each studied metal at each temperature) to one single mathematic law. The objective of this paper is the setup and the exploitation of a global kinetic law, expressing the solid matrix influence on the metal vaporization dynamics. This global kinetic law is obtained from the kinetic rate profiles of $\mathrm{Cd}, \mathrm{Pb}$ and $\mathrm{Zn}$ determined between $650^{\circ} \mathrm{C}$ and $800^{\circ} \mathrm{C}$.

\section{Experimental setup and procedure}

\subsection{Fluidized bed reactor}

The experimental setup scheme, including a fluidized bed reactor and the on-line gas analysis system, is shown in Figure 1. It was previously described in details (Falcoz et al. 2009). Two half-cylinder radiative shells are used to heat the reactor and control its temperature. The hot fluidization gas is introduced into the reactor after going through an electrical resistance. When the reactor is at thermal steady state, a given mass of reactive metal-spiked particles is injected into the bed composed of sand. In order to prevent vaporization of the spiked metals before the particles enter the reactor, particles are injected inside the reactor thanks to a compressed air inlet.

\subsection{On-line gas analysis system}

The gas to be analyzed is injected into the argon plasma torch of an ICP spectrometer (Horiba Jobin Yvon JY 38S). The ICP spectrometer, classically used for liquid analysis, was adapted for 
this purpose. The previously developed calibration method (Falcoz 2007) now allows quantitative measurements.

\subsection{Procedure}

The wastes used during experiments were realistic artificial waste (RAW). They are made from real municipal solid waste and thus they contain organic species. The physical properties of this realistic artificial waste are listed in Table 1.

Table 1: Properties of waste particles

\begin{tabular}{lc}
\hline Parameters & Values \\
\hline Particle mean diameter $(\mathrm{mm})$ & $10+/-5 \%$ \\
Density $\left(\mathrm{kg} \cdot \mathrm{m}^{-3}\right)$ & 0.614 \\
Pore mean diameter $(\mu \mathrm{m})$ & 200 \\
Porosity $(\%)$ & 65.1 \\
\hline
\end{tabular}

The experimental procedure is as follows:

- Measurement of the initial metal concentration in the waste by classical ICP spectrometry (after acid digestion of particles).

- Injection of a given amount of RAW into the fluidized bed when the reactor is at thermal steady state (desired temperature reached).

- On-line measurement of the time course of the metal concentration in exhaust gases by the adapted ICP-OES technique.

\section{General kinetic rate law}

3.1 Determination of the general kinetic rate law from specific kinetic rates 
Experiments were carried out at several temperatures: $650{ }^{\circ} \mathrm{C}, 680{ }^{\circ} \mathrm{C}, 710^{\circ} \mathrm{C}, 740{ }^{\circ} \mathrm{C}, 770{ }^{\circ} \mathrm{C}$, and $800{ }^{\circ} \mathrm{C}$.

At first, the objective was to identify the rate laws governing the vaporization rate for each metal $(\mathrm{r}=\mathrm{dq} / \mathrm{dt})$ versus the metal concentration in the waste (q), taking into account the temperature influence. The different steps of the method were:

- first, measure the profile concentrations for each temperature using the on-line analysis method;

- determine by the inverse method the vaporization rate at the particle level from the on-line diagnostic results;

- finally, identify a kinetic rate law from the vaporization rates determined at various temperatures.

The on-line HM concentration during waste combustion in a fluidized bed is plotted on Figure 2, for two representative temperatures $\left(680^{\circ} \mathrm{C}\right.$ and $\left.800^{\circ} \mathrm{C}\right)$. These quantitative results are consistent. The total quantity of HM released by the burning particles during waste combustion increases with temperature, which is in agreement with Arrhenius law.

The HM vaporization fluxes at the particle level, determined by applying the inverse method with the gaseous concentration profile as an inlet parameter, are plotted on Figure 3. In all cases, the area under the curve increases with temperature, that is to say the higher the temperature the higher the total amount of vaporized metal.

This approach leads to a specific rate law which depends on temperature ( $\operatorname{such}$ as $d q / d t=k(T) q^{n}$ ) for each metal. It was discussed in details previously by our team (Falcoz et al.2009).

Furthermore, it is relevant to determine one single mathematic law from all the experimental specific kinetic curves. This gives a global kinetic law, expressing the solid matrix influence on the metal vaporization dynamics. This global law is normalized (dimensionless expression) in 
order to take into account all studied metals at all temperatures. This global kinetic law is therefore independent of the studied metal.

The general rate law is obtained as follows:

1) Plot the experimental kinetic $(r=f(q))$ for the three metals and the six temperatures (Figure 3).

2) Apply the change of variables $x=\frac{q_{0}-q}{q_{0}-q_{f}}$ and $\mathrm{r}_{\mathrm{ad}}=\mathrm{r} / \mathrm{r}_{\max }$ to obtain both dimensionless metal concentration in waste and dimensionless vaporization rate.

3) Plot $r_{a d}=r / r_{\max }$ versus $x$ for each temperature and each metal (Figure 4): so, normalized curves, integrating the temperature and the metal influence, are obtained.

4) Fit all curves to a $\mathrm{n}^{\text {th }}$-order polynomial $\mathrm{f}(\mathrm{x})$ (Figure 4).

5) Finally, identify the global kinetic rate law to a polynomial $f(x)$.

The mathematical expression $\mathrm{f}(\mathrm{x})$ is obtained from the mean values of both increasing and decreasing points of normalized experimental curves $r / r_{\max }$ versus $\mathrm{x}$. Its mathematical expression is given by:

$$
\begin{aligned}
& \text { If } x \leq x_{m} \text { then } \mathrm{f}(x)=-\frac{5}{6}\left(\frac{x}{x_{m}}\right)^{2}+\frac{11}{6} \frac{x}{x_{m}} \\
& \text { If } x \geq x_{m} \text { then } \mathrm{f}(x)=\frac{1}{2}\left(\frac{x-x_{m}}{1-x_{m}}\right)^{3}-\frac{3}{2}\left(\frac{x-x_{m}}{1-x_{m}}\right)^{2}+1
\end{aligned}
$$

where $\mathrm{x}_{\mathrm{m}}$ is a constant: $\mathrm{x}_{\mathrm{m}}=0.15$. In fact, $\mathrm{x}_{\mathrm{m}}$ represents the HM concentration in the waste from which the vaporization rate starts decreasing.

Let us comment on this threshold value $\mathrm{x}_{\mathrm{m}}$. At the beginning of the metal vaporization process, its concentration in the gas phase is null. As soon as the metal vaporization starts, the metal concentration in the gas increases gradually. Nevertheless, the metal concentration increase is not 
necessarily related to a vaporization rate increase. Indeed, the metal vaporization rate is the instantaneous slope of the transient metal concentration.

The first part of the curve (where $\mathrm{x}<\mathrm{x}_{\mathrm{m}}$ ), is then assimilated to a transient phase, during which the vaporization rate is constant and the gas surrounding the particle is laden with metal.

The metal concentration in the solid phase $\mathrm{q}_{\mathrm{m}}$ when the vaporization rate is maximal $\left(r=r_{\max }\right)$ is calculated from experimental results. Knowing the initial metal concentration $\mathrm{q}_{0}$, the vaporized metal percentage during the first part of the vaporization process (i.e between $r_{a d}=0$ and $r_{a d}=1$ )

is determined by: $\eta_{\mathrm{m}}=\frac{q_{0}-q_{\mathrm{m}}}{q_{0}}$. Table 2 presents the results for cadmium.

Table 2: Values of $\eta_{\mathrm{m}}$ in the case of cadmium $\left(\mathrm{q}_{0}=728 \mathrm{mg} / \mathrm{kg}\right)$

\begin{tabular}{ccc}
\hline Temperature $\left({ }^{\circ} \mathbf{C}\right)$ & $\mathbf{q}_{\mathbf{m}}(\mathbf{m g} / \mathbf{k g})$ & $\boldsymbol{\eta}_{\mathbf{m}}(\mathbf{\%})$ \\
\hline 800 & 695 & 4,5 \\
770 & 702 & 3,6 \\
740 & 689 & 5,4 \\
710 & 688 & 5,5 \\
680 & 699 & 4,0 \\
650 & 709 & 2,7 \\
\hline
\end{tabular}

The values of $\eta_{\mathrm{m}}$ are as low as $5 \%$. So, whatever the considered temperature, the first part of the vaporization process can be neglected. This conclusion is also valid for zinc and lead.

This assumption leads to a second global law $\mathrm{g}(\mathrm{x})$, where the vaporization rate is supposed to be constant and maximal at the beginning of the vaporization process (Figure 5). Its mathematical expression is given by:

$$
\begin{aligned}
& \text { If } x \leq x_{m} \text { then } \mathrm{g}(x)=1 \\
& \text { If } x \geq x_{m} \text { then } \mathrm{g}(x)=\frac{1}{2}\left(\frac{x-x_{m}}{1-x_{m}}\right)^{3}-\frac{3}{2}\left(\frac{x-x_{m}}{1-x_{m}}\right)^{2}+1 \\
& \quad \text { with } \mathrm{x}_{\mathrm{m}}=0.15
\end{aligned}
$$




\subsection{General law validation}

For all metals, the global laws were validated by independent experiments, whose results were not used for identifying the general law. The experimental conditions were strictly identical, with the exception of the initial metal concentrations in waste. The initial cadmium concentrations were $723 \mathrm{mg} / \mathrm{kg}$ for experiments used for identifying the general law and $962 \mathrm{mg} / \mathrm{kg}$ for experiments used for validation. Experiments were performed at $650^{\circ} \mathrm{C}$ and $800^{\circ} \mathrm{C}$.

For cadmium (Figure 6), the global law predicted successfully the experimental profile at $650{ }^{\circ} \mathrm{C}$, whereas it overestimated slightly experimental results at $800{ }^{\circ} \mathrm{C}$.

Concerning lead and zinc, experimental results were well predicted by the global law at both temperatures.

To conclude, the global law proposed in this study can be considered as a general relationship. Therefore it can be very useful to predict any heavy metal vaporization kinetics from burning particles.

\section{Exploitation of the general kinetic rate law}

\subsection{Prediction of the vaporization characteristic time}

A law describing the metal concentration time variations in the solid phase can be obtained by integrating the global law $\mathrm{g}(\mathrm{x})$. Considering only the increasing part of the global law $\mathrm{g}(\mathrm{x})$, we have:

$$
g(x)=-\frac{d q / d t}{r_{\max }}=\frac{1}{2}\left(\frac{x-x_{m}}{1-x_{m}}\right)^{3}-\frac{3}{2}\left(\frac{x-x_{m}}{1-x_{m}}\right)^{2}+1
$$


By applying the change of variables $X=\frac{x-x_{m}}{1-x_{m}}$ and $t^{*}=\frac{r_{\max }}{2\left(q_{0}-q_{f}\right)} t$, we obtain:

$$
\frac{d X}{X^{3}-3 X^{2}+2}=-d t^{*}
$$

After integrating and reducing, we obtain the following equation:

$$
x=1-\sqrt{\frac{3 / 2}{e^{6 t^{*}}+1 / 2}}
$$

$\mathrm{x}$ parameter $\left(x=\frac{q_{0}-q}{q_{0}-q_{f}}\right)$ can be assimilated to the ratio between the vaporization rate at a given time t, $\eta_{M L}=\left(q_{0}-q\right) / q_{0}$, and the final vaporization rate $\eta_{M L, f}=\left(q_{0}-q_{f}\right) / q_{0}$. It is thus a normalized vaporization rate, that is to say the percentage of metal actually vaporized over that of potentially vaporizable.

Because of its mathematical expression, we cannot determine a global vaporization time $\tau$. So a characteristic time $\tau_{95}$ is defined, as the time when $95 \%$ of the potentially vaporizable metal is effectively vaporized.

$$
\tau_{95}=\frac{\ln (600)}{3} \frac{q_{0}-q_{f}}{r_{\max }} \approx 2,13 \frac{q_{0}-q_{f}}{r_{\max }}
$$

\subsection{Prediction of the metal concentration evolution in the waste}

The metal concentration time course in the waste is determined from Equation (5). It is given by:

$$
q=q_{0}-\left(q_{0}-q_{t}\right)\left[1-\sqrt{\frac{3 / 2}{e^{\left(3 r_{\max } /\left(q_{0}-q_{f}\right) t\right.}+1 / 2}}\right]
$$

Figure 7 plots the concentration profiles calculated from the general law $\mathrm{g}(\mathrm{x})$ (Equation 7) and the experimental results, for cadmium, which compare very favorably. This validates the 
mathematical expression $\mathrm{q}=\mathrm{f}(\mathrm{t})$. Therefore, this expression can be used to predict the metal concentration evolution in a waste particle during incineration.

\section{Discussion and conclusions}

The proposed global kinetic law $\mathrm{g}(\mathrm{x})$ takes into account the waste matrix effect on the heavy metal vaporization. It is independent from the studied metal $(\mathrm{Cd}, \mathrm{Pb}$ or $\mathrm{Zn})$. Its mathematical expression is very simple; so, it can be easily used in a complex combustion model.

Nevertheless, $g(x)$ gives a normalized kinetic rate $\left(r / r_{\max }=f(x)\right)$ and it does not consider the temperature influence on the heavy metal concentration. To get quantitative profiles, such as $\mathrm{r}=$ $\mathrm{f}(\mathrm{q})$, it is necessary to know or to determine $\mathrm{r}_{\max }, \mathrm{q}_{0}$ and $\mathrm{q}_{\mathrm{f}}$.

Therefore, potential users of this global law should, beforehand:

- Determine $\mathrm{q}_{0}$ : the initial metal concentration in the waste is generally well known or easy to measure;

- Determine $\mathrm{q}_{\mathrm{f}}$ : the final metal concentration in the waste can be measured in ashes, or determined by thermodynamics calculations;

- Determine $r_{\max }$ : the maximal vaporization rate depends on temperature. It is calculated by identification to the Arrhenius law $r_{\max }=k_{0} e^{\frac{-E_{a}}{R T}}$. Parameters values for $r_{\max }$ determination are listed in Table 3.

- Apply the following changes of variable to finally obtain quantitative kinetic rate profiles $(g=f(x) \rightarrow r=f(q)):$

$$
\begin{aligned}
& r=g \cdot r_{\max } \\
& q=q_{0}-x\left(q_{0}-q_{f}\right)
\end{aligned}
$$


Table 3: Arrhenius parameter values for $r_{\max }$ calculus

\begin{tabular}{ccc}
\hline Elements & $\mathbf{E}_{\mathbf{a}}(\mathbf{k J} / \mathbf{m o l})$ & $\mathbf{k}_{\mathbf{0}}\left(\mathbf{m g} \cdot \mathbf{k g}^{-1} \cdot \mathbf{s}^{-1} \cdot \mathbf{m}^{-2}\right)$ \\
\hline $\mathbf{P b}$ & 167,0 & $6,1 \cdot 10^{12}$ \\
$\mathbf{Z n}$ & 156,4 & $1,3 \cdot 10^{12}$ \\
$\mathbf{C d}$ & 159,0 & $4,3 \cdot 10^{12}$ \\
\hline
\end{tabular}

Knowing $\mathrm{q}_{0}, \mathrm{q}_{\mathrm{f}}$ and $\mathrm{r}_{\max }$, it is then possible to predict, for a given temperature:

- the vaporization kinetic profile $(r=f(q))$,

- the metal concentration time course in the waste, $(q=f(t))$

- the duration of the vaporization process $\left(\tau_{95}\right)$.

Further work will consist in integrating this global kinetic rate law into a global model of municipal solid waste combustion, in order to simulate the effects of operating parameters on the heavy metal behavior.

\section{Nomenclature}

$\mathrm{E}_{\mathrm{a}}$ : activation energy, $\mathrm{kJ} / \mathrm{mol}$

$\mathrm{g}$ : dimensionless global kinetic rate law

$\mathrm{k}_{0}$ : pre-exponential factor, $\mathrm{mg} \cdot \mathrm{kg}^{-1} \cdot \mathrm{s}^{-1} \cdot \mathrm{m}^{-2}$

$\mathrm{q}_{0}$ : initial metal concentration in waste, $\mathrm{mg} / \mathrm{kg}$

q: metal concentration in waste, $\mathrm{mg} / \mathrm{kg}$

$\mathrm{q}_{\mathrm{f}}$ : final metal concentration in waste, $\mathrm{mg} / \mathrm{kg}$

$\mathrm{q}_{\mathrm{m}}$ : metal concentration in waste at the maximum vaporization rate, $\mathrm{mg} / \mathrm{kg}$

$\mathrm{r}$ : metal vaporization rate, $\mathrm{mg} \cdot \mathrm{kg}^{-1} \cdot \mathrm{s}^{-1} \cdot \mathrm{m}^{-2}$

$\mathrm{r}_{\mathrm{ad}}$ : dimensionless vaporization rate

$\mathrm{r}_{\max }$ : maximum vaporization rate, $\mathrm{mg} \cdot \mathrm{kg}^{-1} \cdot \mathrm{s}^{-1} \cdot \mathrm{m}^{-2}$

$\mathrm{x}$ : metal dimensionless concentration in waste 
$\eta_{M L}$ : vaporization rate at a given time

$\eta_{M L, f}:$ final vaporization rate

$\eta_{m}$ : vaporized metal percentage during the first part of the vaporization process

$\tau_{95}$ : vaporization characteristic time, $\mathrm{s}$

\section{References}

Abanades, S.; Flamant, G.; Gauthier, D., 2001, Modeling of heavy metal vaporisation from a mineral matrix. J. Hazard. Mater. 88(1), 75-94.

Abanades, S., Flamant, G., Gauthier, D., 2003, The kinetics of vaporization of a heavy metal from a fluidized waste by an inverse method. Combustion and Flame. 134(4), 315-326.

Abanades, S., Flamant, G., Gauthier D., Tomas S., Huang L., 2005, Development of an inverse method to identify the kinetics of vaporization of heavy metal during waste incineration in fluidized bed. J. Hazard. Mater. 124, 19-26.

Barton, R.G.; Clark, W.D.; Seeker, W.R., 1990, Fate of metals in waste combustion systems. Combust. Sci. and Tech. 74, 327-342.

Belevi, H.; Langmeier, M., 2000, Factors determining the element behavior in municipal solid waste incinerators. 2. Laboratory experiments. Environ. Sci. Technol. 34 (12), 2507-2512.

Chandler, A,J.; Eighmy, T,T; Hartlén, J; Hjelmar, O; Kosson, D,S; Sawell, S,E; Van der Sloot, H.A.; Vehlow, 1997, J. Municipal Solid Waste Incinerator Residues, The International Ash Working Group (IAWG), Elsevier Science.

Corella, J., Toledo, J.M., 2000 Incineration of doped sludges in fluidized bed. Fate and partitioning of six targeted heavy metals I. Pilot plant used and results. J. Hazard. Mater., 80 (13), 81-105.

Falcoz, Q., Gauthier, D., Abanades, S., Flamant, G., 2007, On-line analysis of vaporized cadmium in high temperature processes, Int. Journal on Energy for a Clean Environ. 8(3), 259272.

Falcoz, Q., Gauthier, D., Abanades, S., Flamant, G., Patisson F., 2009, Kinetic rate laws of Cd, $\mathrm{Pb}$, and $\mathrm{Zn}$ vaporization during municipal solid waste incineration, Environ. Sci. technol. 43(6), 2184-2189.

Frandsen, F.; Dam-Johansen, K.; Rasmussen, P., 1994, Trace elements from combustion and gasification of coal - an equilibrium approach. Prog. Energy Combust. Sci. 20, 115-138.

Ho, T.C., Chu, H.W., Hopper J.R., 1993, Metal volatilization and separation during incineration, Waste Management. 13 (5-7), 455-466. 
Liu, J., Abanades, S., Gauthier, D., Flamant, G., Zheng, C., Lu, J., 2005, Determination of kinetic laws for toxic metals release during thermal treatment of model waste in a fluid-bed reactor. Environ. Sci. Technol. 39, 9331-9336.

Marias, F., Puiggali, J.R., Flamant, G., 2001, Modeling for Simulation of Fluidized-Bed Incineration Process. AIChE J. 47 (6), 1438-1460.

Ménard, Y., Asthana, A., Patisson, F., Sessiecq, P., Ablitzer, D., 2006, Thermodynamic Study of Heavy Metals Behaviour During Municipal Waste Incineration. Process Safety and Environmental Protection. 84 (4), 290-296.

Poole D., Argent B.B., Sharifi V.N., Swithenbank J., 2008, Prediction of the distribution of alkali and trace elements between the condensed and gaseous phases in a municipal solid waste incinerator, Fuel 87(7), 1318-1333.

Scharnhorst, W., Ludwig, C., Wochele, J., Jolliet O., 2007, Heavy metal partitioning from electronic scrap during thermal End-of-Life treatment. Science of the Total Environment. 373 (23), 576-584.

Toledo, J.M., Corella, J., Corella L.M., 2005, The partitioning of heavy metals in incineration of sludges and waste in a bubbling fluidized bed: 2 . Interpretation of results with a conceptual model. J. Hazard. Mater. 126 (1-3), 158-168.

Wey, M.Y., Hwang, J.H., Chen J.C., 1996, The behavior of heavy metals $\mathrm{Cr}, \mathrm{Pb}$ and $\mathrm{Cd}$ during waste incineration in fluidized bed under various chlorine additives, Journal of Chem. Eng. of Japan. 29, 494-500.

Youcai, Z., Stucki, S., Ludwig, C., Wochele, J., 2004, Impact of moisture on volatility of heavy metals in municipal solid waste incinerated in a laboratory scale simulated incinerator, Waste Management 24 (6), 581-587.

Zhang, H., He, P.J., Shao, L.M., 2008, Fate of heavy metals during municipal solid waste incineration in Shanghai. J. Hazard. Mater, 156, 365-373.

\section{Acknowledgements}

This study was supported by ADEME (Agence de l'Environnement et de la Maîtrise de l'Energie) and Languedoc Roussillon Regional Council. 


\section{Figure captions}

Figure 1: Experimental set-up of the fluidized bed reactor coupled to the ICP spectrometer

Figure 2: Time course of HM concentration in the outlet gas from waste particle combustion. Case of $\mathrm{Pb}, \mathrm{Zn}$ and $\mathrm{Cd}$ at $680^{\circ} \mathrm{C}$ and $800^{\circ} \mathrm{C}$.

Figure 3: Experimental kinetic rate, $\mathrm{Cd}, \mathrm{Zn}$ and $\mathrm{Pb}$ at $680^{\circ} \mathrm{C}$ and $800^{\circ} \mathrm{C}$.

Figure 4: Normalized kinetic rates fitted by $\mathrm{f}(\mathrm{x})$ law for $\mathrm{Pb}, \mathrm{Zn}$ and $\mathrm{Cd}$ at several temperatures.

Figure 5: Global law determination: normalized kinetic rates fitted by $\mathrm{g}(\mathrm{x})$ law for $\mathrm{Pb}, \mathrm{Zn}$ and $\mathrm{Cd}$ at several temperatures.

Figure 6: Validation of the global law, Cd case at $650^{\circ} \mathrm{C}$ and $800^{\circ} \mathrm{C}$.

Figure 7: Comparison between the predicted (by general law) and the experimental concentration profiles in the solid phase, $\mathrm{Cd}$ case at several temperature between $650^{\circ} \mathrm{C}$ and $800^{\circ} \mathrm{C}$. 


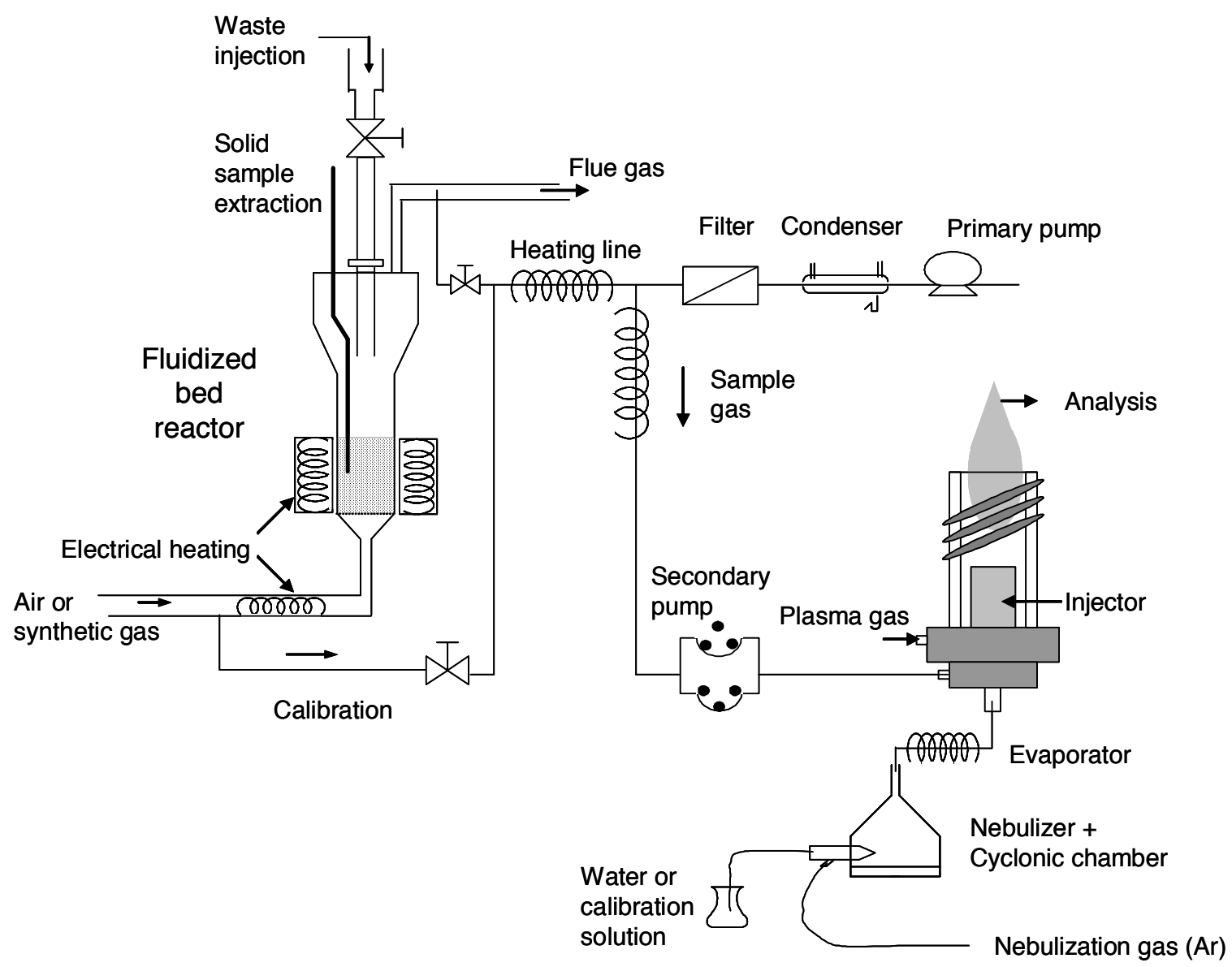

Figure 1: Experimental set-up of the fluidized bed reactor coupled to the ICP spectrometer 


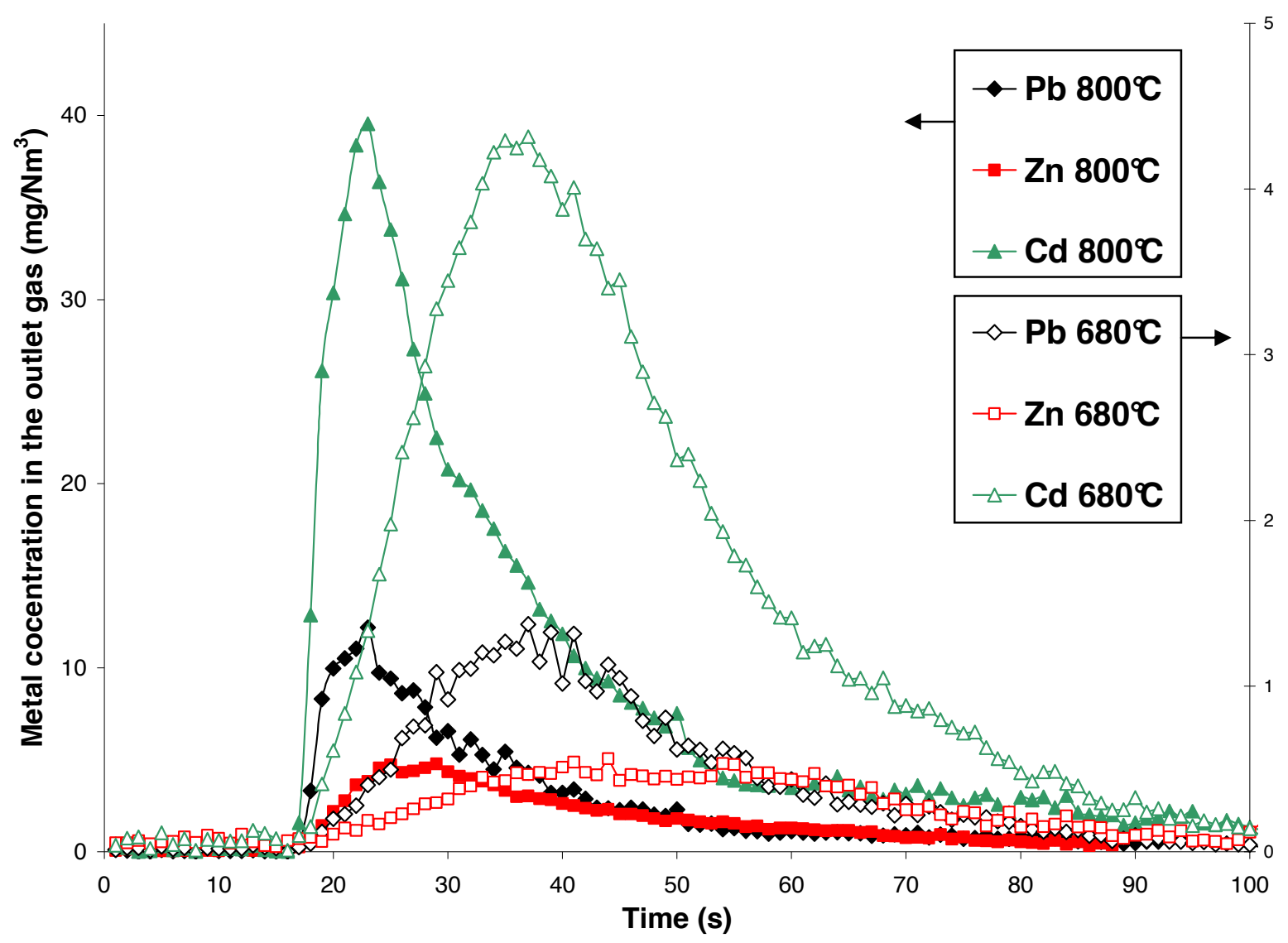

Figure 2: Time course of HM concentration in the outlet gas from waste particle combustion. Case of $\mathrm{Pb}, \mathrm{Zn}$ and $\mathrm{Cd}$ at $680^{\circ} \mathrm{C}$ and $800{ }^{\circ} \mathrm{C}$ 


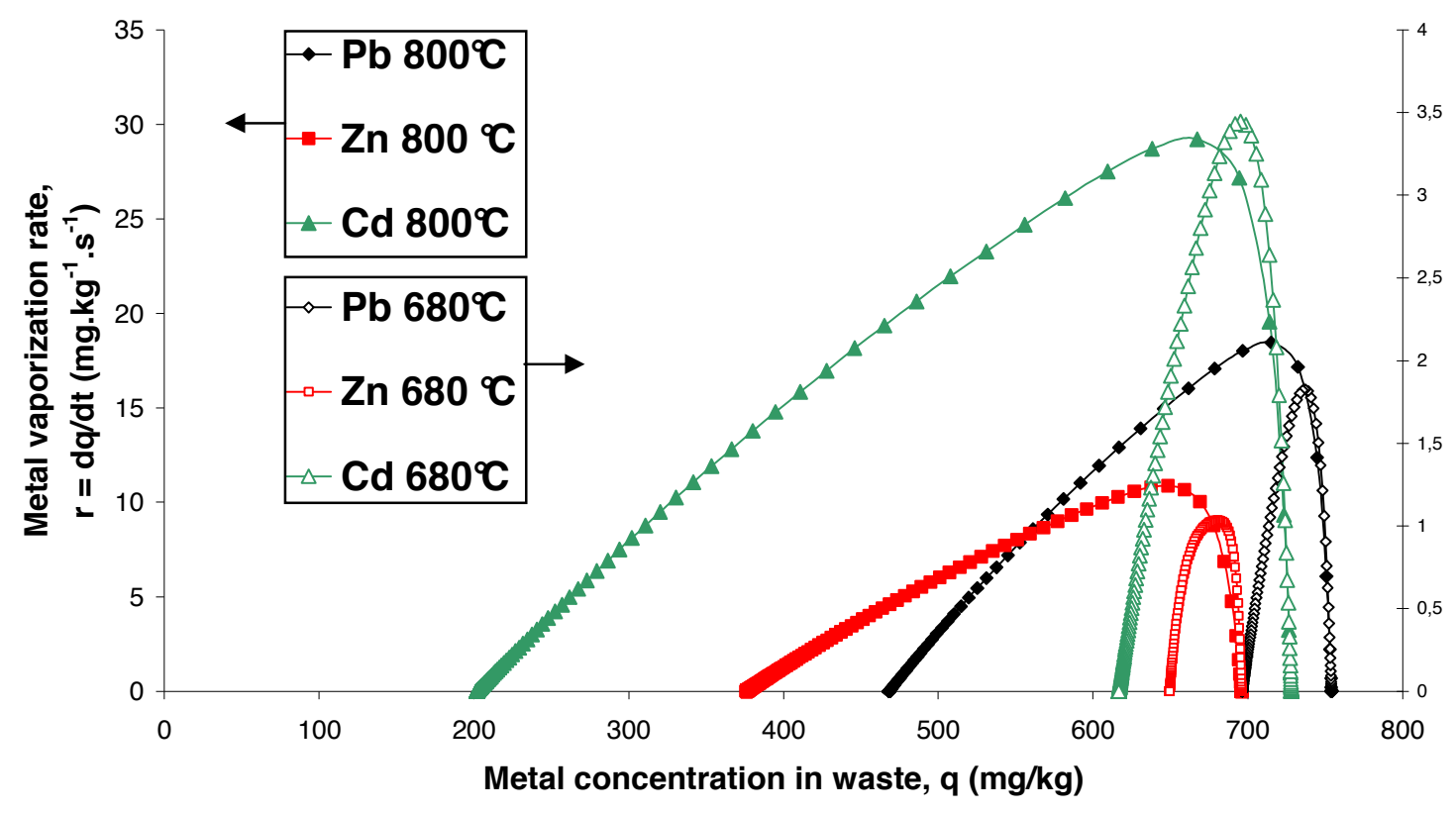

Figure 3: Experimental kinetic rate, $\mathrm{Cd} \mathrm{Zn}$ and $\mathrm{Pb}$ at $680^{\circ} \mathrm{C}$ and $800^{\circ} \mathrm{C}$ 


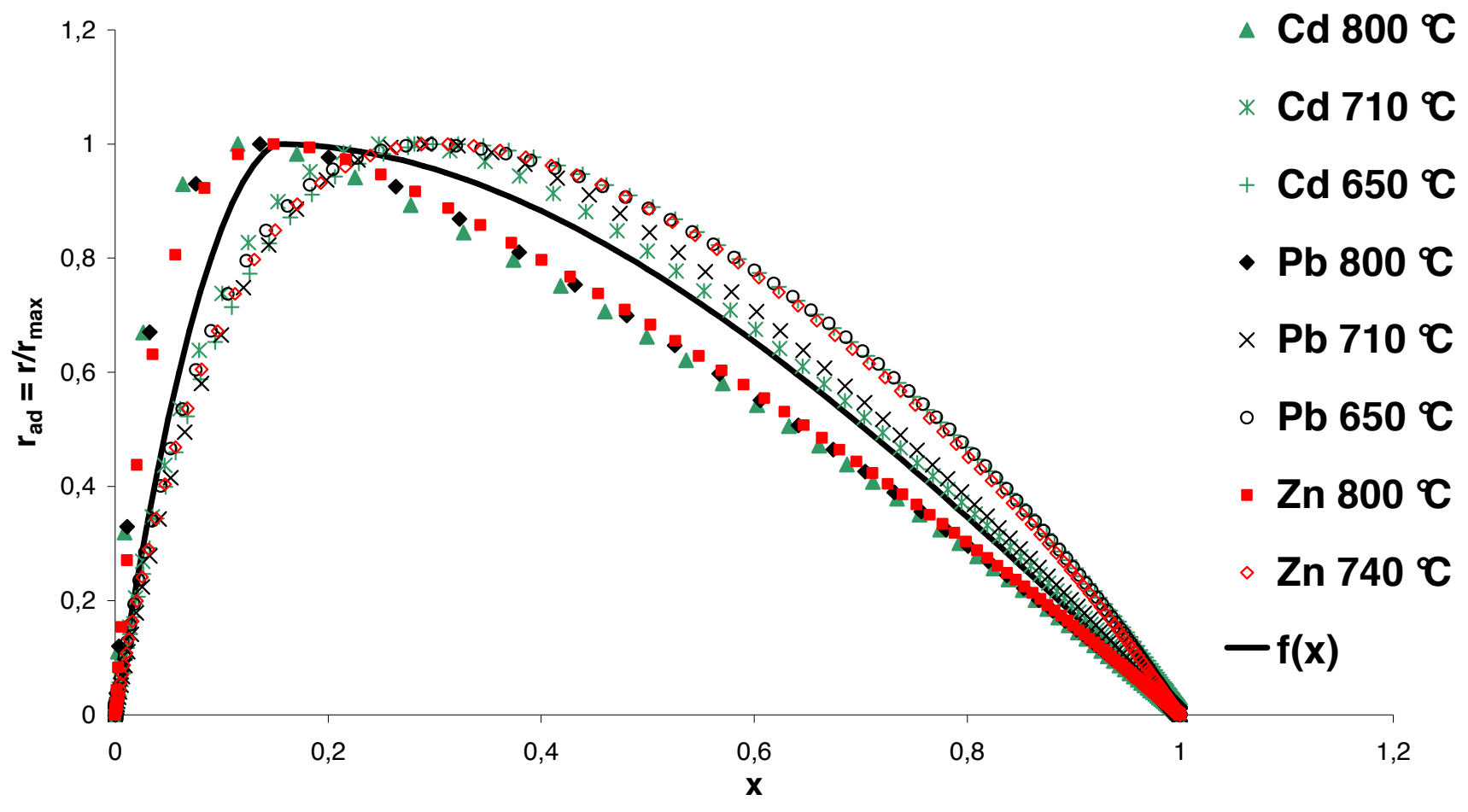

Figure 4: Normalized kinetic rates fitted by $\mathrm{f}(\mathrm{x})$ law for $\mathrm{Pb}, \mathrm{Zn}$ and $\mathrm{Cd}$ at several temperatures. 


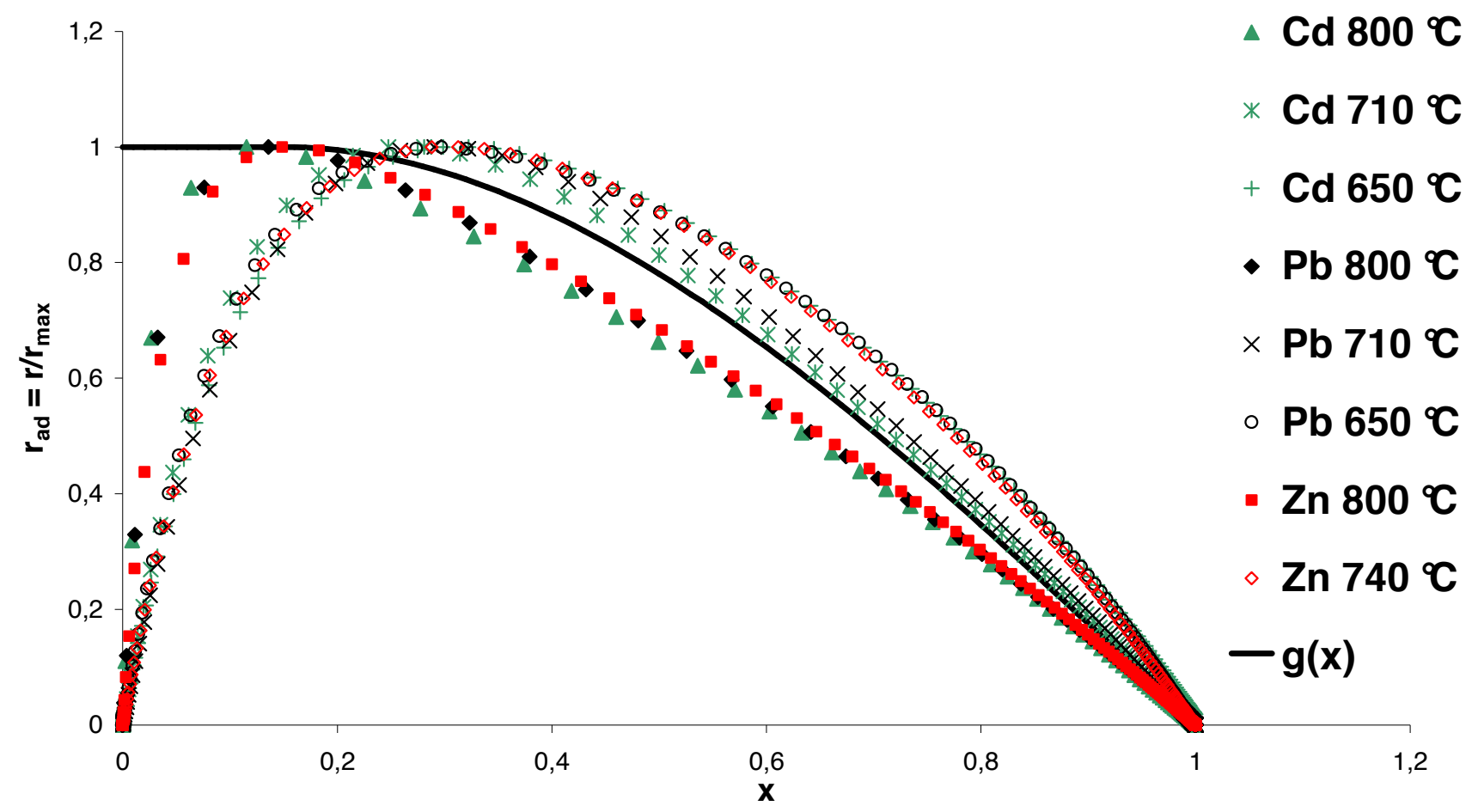

Figure 5: Global law determination: normalized kinetic rates fitted by $\mathrm{g}(\mathrm{x})$ law for $\mathrm{Pb}, \mathrm{Zn}$ and $\mathrm{Cd}$ at several temperatures. 


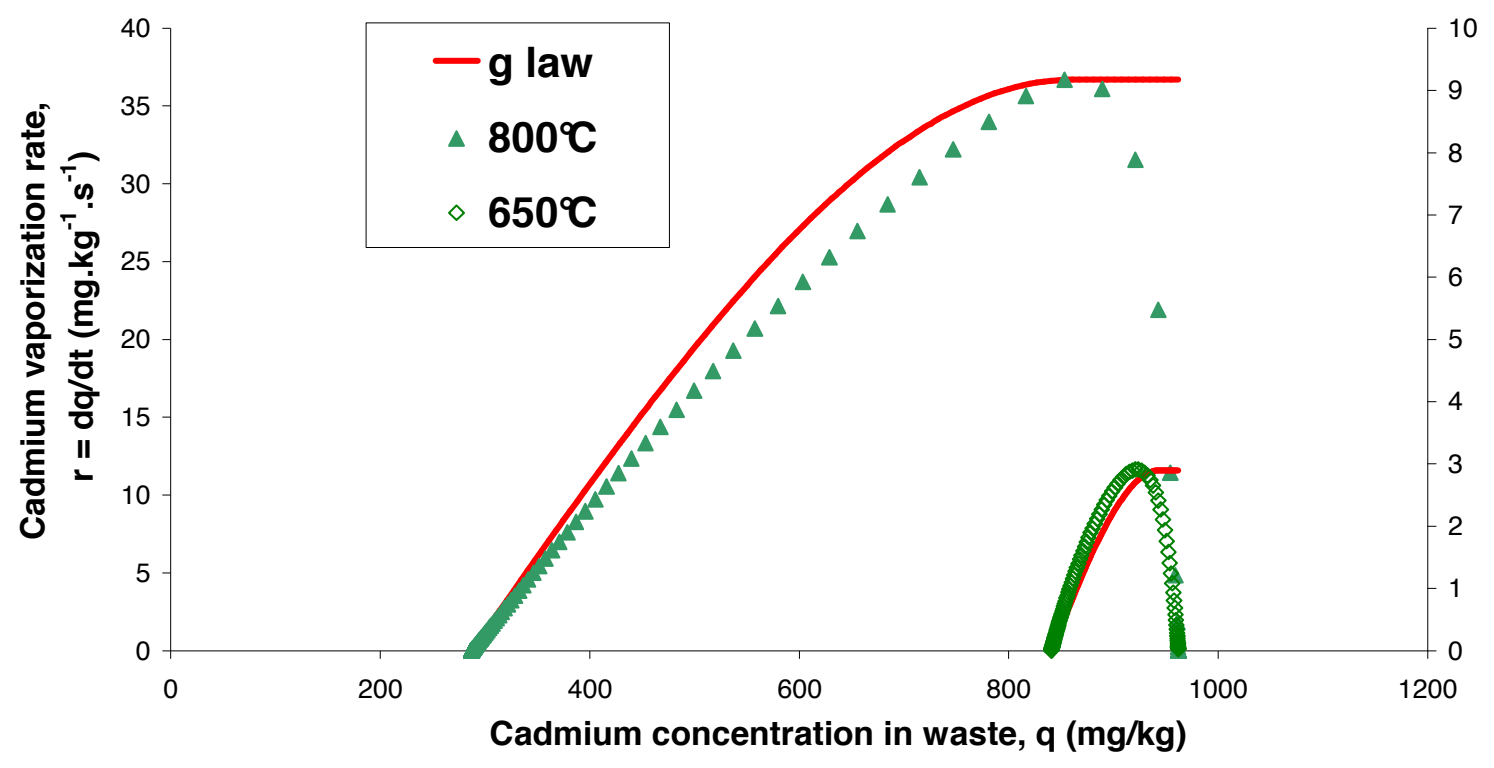

Figure 6: Validation of the global law, $\mathrm{Cd}$ case at $650^{\circ} \mathrm{C}$ and $800^{\circ} \mathrm{C}$. 


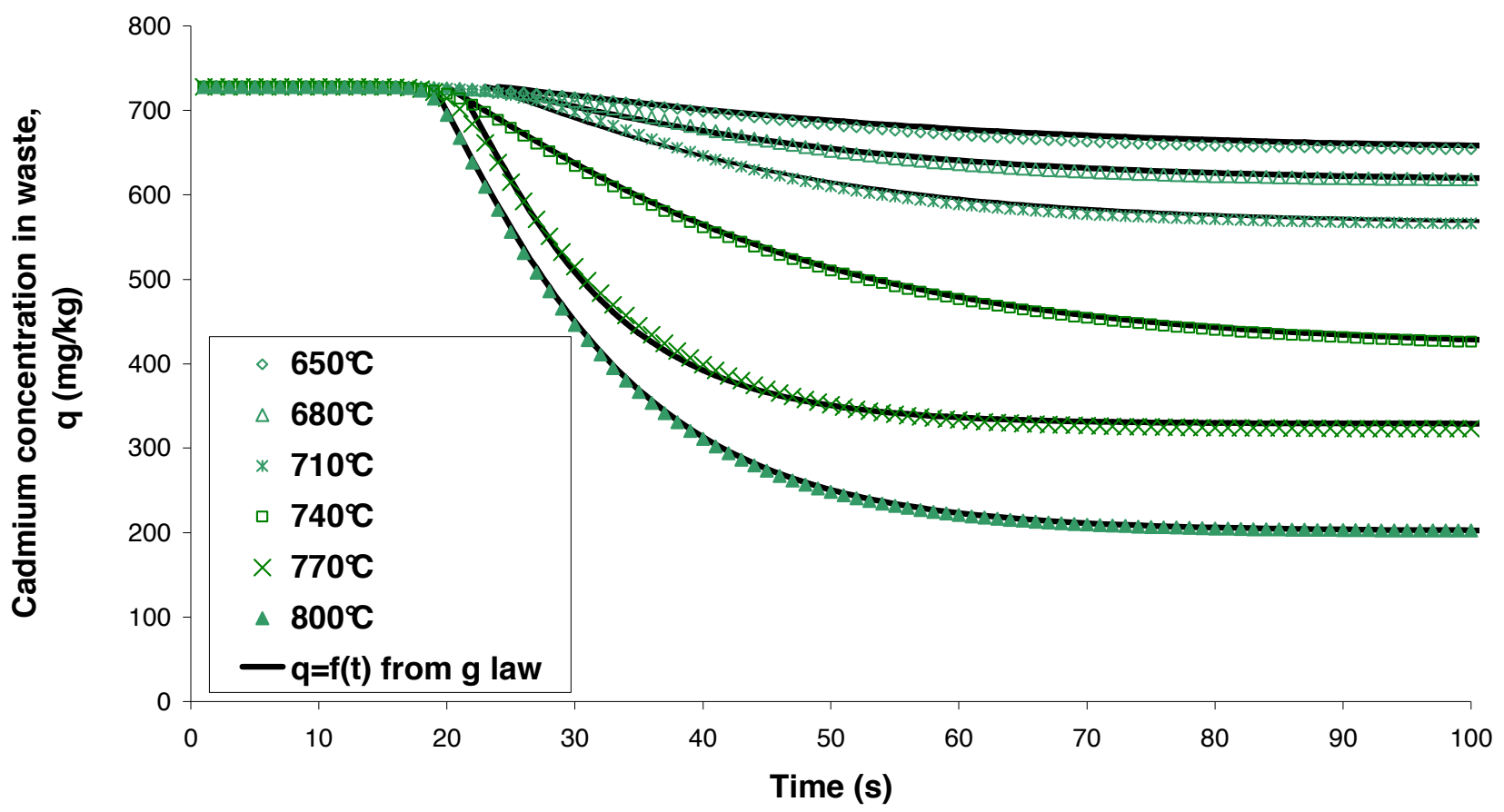

Figure 7: Comparison between the predicted (by general law) and the experimental concentration profiles in the solid phase, $\mathrm{Cd}$ case at several temperature between $650^{\circ} \mathrm{C}$ and $800^{\circ} \mathrm{C}$. 